\title{
MODIFICATION OF EAPC-XYL BY PSEUDOMONAS LIPASES BACTERIA TO REMOVE ACRYLIC FROM THE MURAL OIL PAINTINGS
}

\author{
Abeer F. ELHAGRASSY \\ Department of Conservation, Faculty of Archaeology, Fayoum University, Egypt \\ E.mail: afa01@,fayoum.edu.eg
}

\begin{abstract}
This paper focuses on the removal of acrylic polymer layers from the surfaces of mural paintings, as one of the serious problems faced by conservators. Nanostructured fluids containing water is a great solution for the immiscible or partially miscible polymer with water. The de-wetting of the polymer layer is usually an essential step to achieve efficient removal. EAPC-XYL system was often used for the removal of paraloid B72 but unfortunately, it has an effect on the noble patina of the pigments. The addition of Pseudomonas stutzeri as a source of lipase enzyme increases the efficiency of the EAPC-XYL in short time which helps in removing of the acrylic polymers without affecting the pigments.
\end{abstract}

The examination by SEM showed that the applying EAPC-XYL/ Pseudomonas stutzeri for only one hour has the effect of removing the polymer's layers from the mural paintings without affecting the pigments. The FTIR analysis after application showed that the functional groups of the binding medium of the mural paintings is absence of paraloid B72.

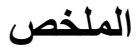

تركز هذه الورقة على إزالة طبقات البوليمر

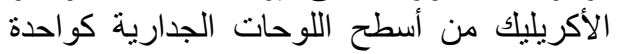

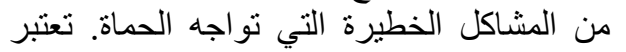

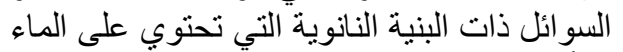

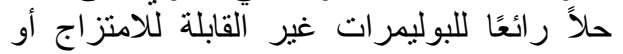

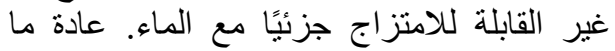

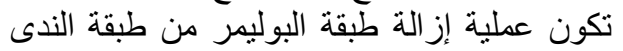
خطوة أساسية لتحقيق الإز الة الفعالة. غالبًا ما كان نظام EAPC-XYL يستخدم لإز الة البار الويد

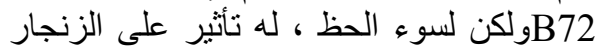

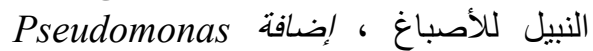
SStutzeri يAPC-XYL الاكريليك دون التأثير على الآصباغ.

أظهر الفحص الذي أجرته SEM أن تطبيق EAPC-XYL / Pseudomonas stutzeri لمدة ساعة واحدة فقط له تأثثير على إزالة طبقات البوليمرات من اللوحات الجدارية دون إنداتئ التأثير

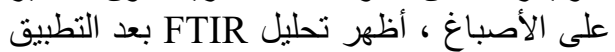

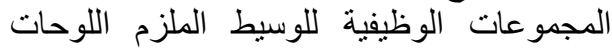

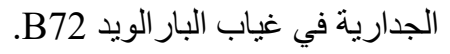

Nano-emulsions, Acrylic polymer, cleaning, oil wall paintings, conservation, Pseudomonas stutzeri

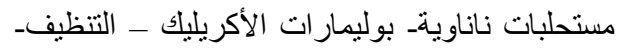

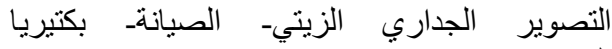
الباسيدو موناس. 


\section{INTRODUCTION}

Mural paintings are degraded due to the natural ageing of their components. The degradation process occurs at the surface of the pigment layer which leads to the weakness of these mural paintings, and the loss of pigment layers in some cases. ${ }^{1}$

Polymers and Acrylics were used as consolidants for these murals. They are still widespread within the conservation field, although they have produced critical degradation with destructive effects. ${ }^{2}$ Their continuous popularity is due to the possibility of applying the same materials at the beginning of the conservation interference and posteriorly reapplied after the conservation process. ${ }^{34}$

When polymers are applied on mural paintings, a surface microfilm is formed even at low concentration. This microfilm certainly changes the mural paintings surface's porosity and permeability, causing mechanical stresses and photo-degradation of the pigments. ${ }^{56}$

Removing aged polymers from conserved mural paintings must be carried out without affecting the patina of the pigments. This is a critical problem due to the heterogeneous and porosity of the pigment layer itself. Furthermore, as the main reason for polymer degradation is a drastic loss of solubility, it makes their removal by traditional chemical solvent yet more difficult. ${ }^{78}$

Nanoemulsions consist of oil, water and an emulsifier which is necessary for the formation of nano-sized droplets that help to decrease the interfacial tension, the surface energy per unit area between the water phase and the oil one of the emulsions. The addition of an emulsifier is critical for the stabilising of nanoemulsions through repugnant steric hindrance and electrostatic interactions. ${ }^{9} 1011$

Treatment by nanoemulsion using (SDS), 1-pentanol (1-PeOH) as a co-surfactant, addition to a small amount of $\mathrm{p}$-xylene and nitro diluent were applied at three mural paintings : the Loggia del Bigallo in Florence, the Filippo Lippi frescoes in Prato Cathedral, and 'a secco' painting in the Villa del Barone in Prato and the results were acceptable. ${ }^{12}$

An oil-in-water nanoemulsion containing SDS/dodecane/n-butanol/ $\mathrm{H} 2 \mathrm{O}$ was efficient in the removal of the polar materials from mural paintings of the Oratory of San Nicola al

\footnotetext{
${ }^{1}$ Mora, "Causes of Deterioration of Mural paintings" 1974

2 Giorgi, et al, "New methodologies for the conservation of cultural heritage: micellar solutions, microemulsions, and hydroxide nanoparticles", 2010

${ }^{3}$ Tintori, "Studies for the preservation of the frescoes by Giotto in the Scrovegni Chapel at Padua. The state of conservation of the frescoes and the principal technical conservation problems", 1963

${ }^{4}$ Masaaki, "The consolidation and the conservation of ancient Japanese wall paintings"1996

${ }^{5}$ Wyszecki and Stiles, "Color Science Concepts and Methods. Quantitative Data and Formulae",2000

${ }^{6}$ Baglioni, et al, "Smart cleaning of cultural heritage: a new challenge for soft nanoscience", 2012

${ }^{7}$ Carretti, et al., "Oil-in-water microemulsions to solubilize acrylic copolymers: application in cultural heritage conservation", 2001,

${ }^{8}$ Carretti, et al., "Microemulsions and Micellar Solutions for Cleaning Wall Painting Surfaces", 2005

${ }^{9}$ Giorgi, et al, "Microemulsions for the cleaning of wall paintings", 2008

${ }^{10}$ Giorgi, et al, "New methodologies for the conservation of cultural heritage: micellar solutions, microemulsions, and hydroxide nanoparticles", 2010

${ }^{11}$ Baglioni, et al, op.t, 2012

${ }^{12}$ Carretti, et al., "Microemulsions and Micellar Solutions for Cleaning Wall Painting Surfaces", 2005
}

- 190 - Modification of EAPC-XYL by Pseudomonas lipases bacteria to remove acrylic ... 
Ceppo. $^{13} 1415$

Nanoemulsions are ordinarily prepared in two process: first a microemulsion that is then converted to a nanoemulsion. ${ }^{16}$

Nanoemulsions Fig. 1, have smart properties like nanodroplet size, high surface area per unit volume, tunable rheology, kinetic stability of liquid-in-liquid dispersions, and limpid appearance. $^{17}$

The formulation of o/w (oil/water) nanoemulsions requires small amounts of solvent which reduces the toxicity and environmental impact. The cleaning process with nanoemulsions provides a controlled cleaning process without affecting the pigments. ${ }^{18}$

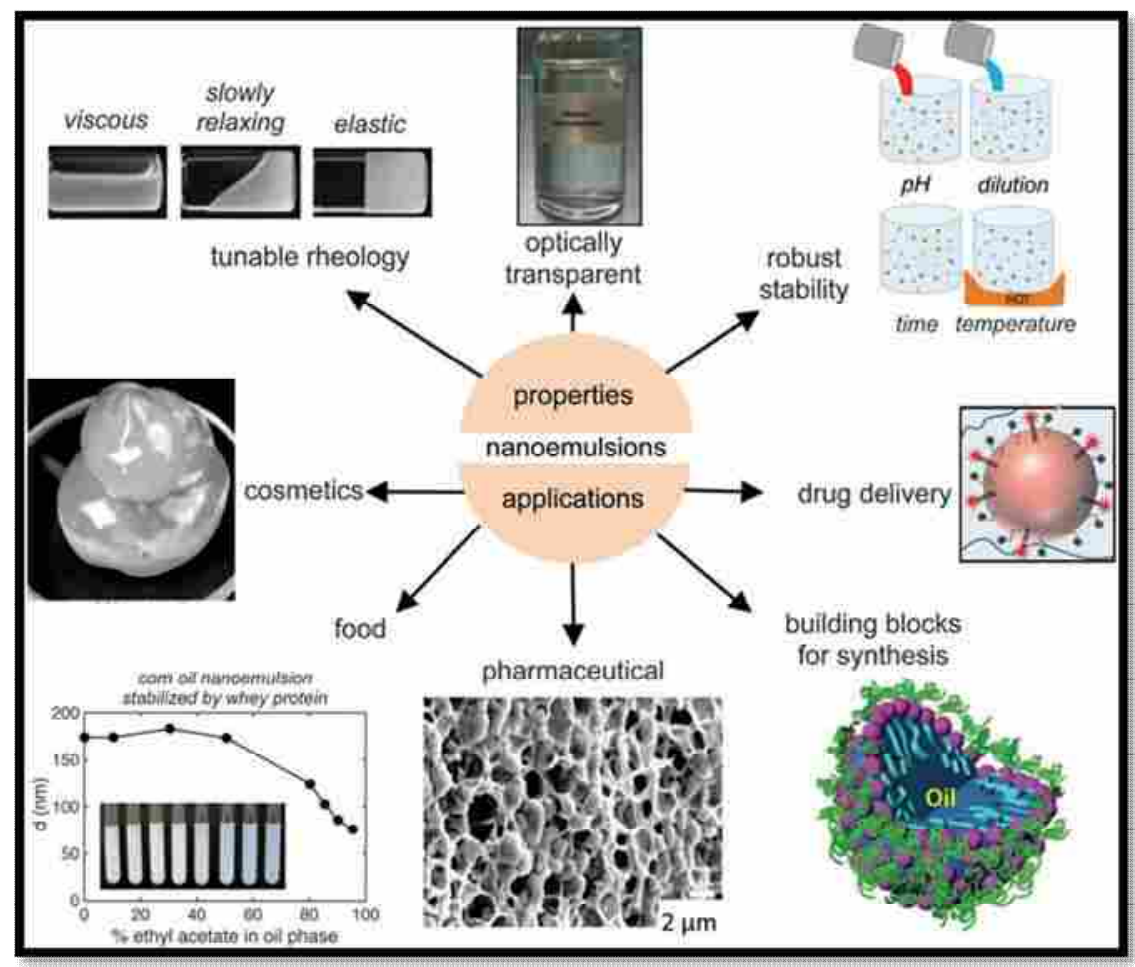

Fig.1 Application and properties of nanoemulsion ${ }^{19}$

EAPC is a fluid that is composed of five components: water, sodium dodecyl sulfate (SDS), 1-pentanol $(\mathrm{PeOH})$, propylene carbonate $(\mathrm{PC})$, and ethyl acetate (EA). EAPC provides

\footnotetext{
${ }^{13}$ Carretti, et al., "Oil in water nanocontainers as low environmental impact cleaning tools for works of art: two case studies", 2007

${ }^{14}$ Raudino, et al, "Polymer Films Removed from Solid Surfaces by Nanostructured Fluids: Microscopic Mechanism and Implications for the Conservation of Cultural Heritage", 2015

${ }^{15}$ Raudino, et al, Probing the Cleaning of Polymeric Coatings by Nanostructured Fluids: A QCM-D Study", 2017

${ }^{16}$ Singha et al, "Nanoemulsion: Concepts, development and applications in drug delivery", 2017

${ }^{17}$ Baglioni et.al, "Nanostructured fluids from degradable nonionic surfactants for the cleaning of works of art from polymer contaminants" 2014

${ }^{18}$ Gupta et.al, "Nanoemulsions: formation, properties and applications", 2016

${ }^{19}$ Gupta et.al, "Nanoemulsions: formation, properties and applications", 2016
} 
effective results in the removal of methacrylic/acrylic or vinyl/acrylic copolymers but unfortunately it causes some colour change. ${ }^{20}$

EAPC system was successfully used before to remove polysiloxane resin applied on mural paintings in Nazareth (Israel) and is considered as one of the most efficient systems for removing polymers for now. ${ }^{21} 2223$

The present study is concerned with using Pseudomonas stutzeri as a source of Lipase which can increase the effect of EAPC, and the effect of using Pseudomonas stutzeri to remove any other organic matter. We will also point out the effective application time. Pseudomonas stutzeri is used to remove animal glue from protected mural paintings. ${ }^{24} 2526$

The mosque of El Gamaly Yosouf is one of the monuments where the mural oil paintings were consolidated on multiple occasions with polymers and acrylic (Fig. 2). Fragments were taken to be examined and analysed, but all the results showed only polymers without the components of the layer.

The aim of this study is to modify the nanoemulosion to make it safe to be used for mural paintings, without affecting the pigment of the oil wall paintings.
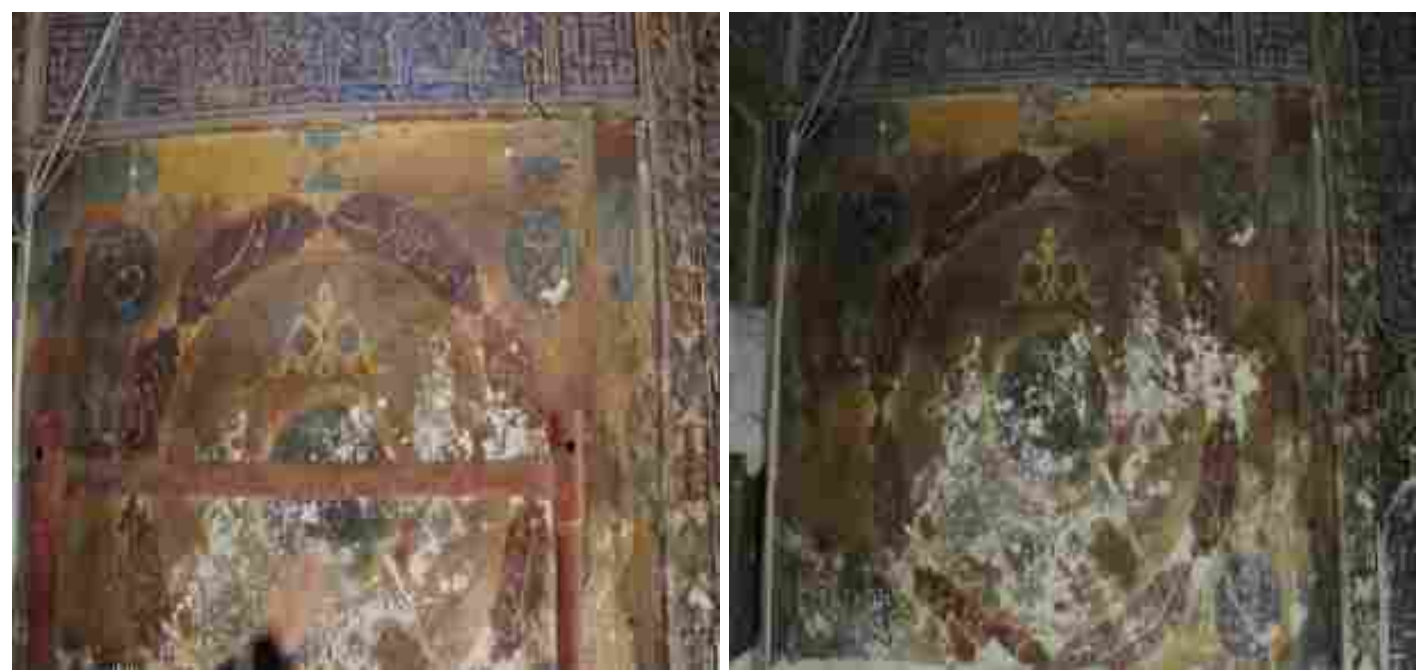

Fig. 2. The mural oil paintings of the mosque present the name of righteous Caliphs and Ahl el-Kahf names.

\footnotetext{
${ }^{20}$ Baglioni, et al, "Smart cleaning of cultural heritage: a new challenge for soft nanoscience" 2012

${ }^{21}$ Cappitelli, "Biocleaning of Cultural Heritage Surfaces", 2016

${ }^{22}$ Giorgi, et al, "Microemulsions for the cleaning of wall paintings" 2008.

${ }^{23}$ Giorgi, et al, "New methodologies for the conservation of cultural heritage: micellar solutions, microemulsions, and hydroxide nanoparticles", 2010.

${ }^{24}$ Lustrato et al, "Fast biocleaning of mediaeval frescoes using viable bacterial cells", 2012

${ }^{25}$ Rosado et al, ) "Enzymatic Monitorization of Mural Paintings Biodegradation and Biodeterioration”, 2013

${ }^{26}$ ElHagrassy "Bio-restoration of mural paintings using viable cells of Pseudomonas stutzeri and characterization of these murals", 2019
}

- 192 - Modification of EAPC-XYL by Pseudomonas lipases bacteria to remove acrylic ... 


\section{MATERIALS AND METHODS}

\section{Chemicals and bacteria}

\section{(A) Chemicals}

Sodium dodecyl sulfate (Sigma-Aldrich), 1-pentanol (Sigma-Aldrich), ethyl acetate (PioChem), p-xylene (Sigma-Aldrich), ethyl acetate (SigmaAldrich) and Distilled Water (PioChem) were used without purification. Furthermore, Broth media was purchased (Z699187- Sigma-Aldrich) and Paraloid B72 was purchased from (PioChem, India).

\section{Bacteria}

Viable cells of Pseudomonas stutzeri ATCC 17589 strain (American Type Culture Collection, Rockville, MD, USA).

\section{Preparing replica and artificial aging}

In order to evaluate the performance of nanoemulsion, a cubic replica size of $5 \mathrm{~cm}$ of the mural oil paintings was prepared and aged. Ten cycles of thermal aging were carried out for 8 hours in an oven at $60^{\circ} \mathrm{C}$ followed by 8 hours in room temperature. ${ }^{27}$

\section{FTIR Spectroscopy}

Absorption spectra in the IR region were collected using a Nicolet Magna 75 FTIR spectrometer. Thirty-two signal-averaged scans acquired the samples. Few milligrams of each sample were mixed in $\mathrm{KBr}$ (IR grade, Merck) pellet performed in accordance with ASTM E334. The acrylic material was extracted by iodoform 95\% (BioChem company, India) to avoid the painted pigments elements.

\section{SEM- EDX}

SEM images were taken using a Jeol (Tokyo, Japan) JSM 5600 LV equipped with an Oxford Instruments 6587 EDX microanalysis detector. The images were taken under low vacuum conditions where samples did not show any charging effects. EDX microanalysis was carried out to obtain information about the elemental composition of the sample.

\section{Spectrophotometer}

Colour - E Y E- 3100- Spectrophotometer - operation manul, S D L Company.

\section{Preparation of the nanoemulsion}

Two systems were used in this study, the traditional EAPC and EAPC after adding viable Pseudomonas stutzeri cells. EAPC system consists of five components which are: "SDS, $3.7 \%$, 1-pentanol, 7\%, ethyl acetate, $8 \%$, propylene carbonate, $8 \%$ in $\mathrm{H}_{2} \mathrm{O}, 73.3 \%$, In addition to using the classical XYL system which consists of p-xylene, 2.5\%, SDS, 3.9\%

\footnotetext{
${ }^{27}$ Prada, J.L. et al., "Laboratory Tests Simulating the Weathering Processes of the Stone of Sant Miquel Church in Cardona (Barcelona, Spain), Protection and Conservation of Cultural Heritage of the Mediterranean Cities", 2002
} 
and 1-pentanol, $6.5 \%$ in $\mathrm{H}_{2} \mathrm{O}, 89.1 \%$." 28

This study uses Pseudomonas stutzeri as a source of Lipase catalyst to remove the organic solvent and acrylic polymer. The Pseudomonas stutzeri has been added as a final step in preparing the previous nanoemulsion; it has then been dispersed using a stirrer set up at 500 rpm. Finally, it was applied on the replica.

\section{RESULTS}

\section{FTIR analyses}

The analyses by FTIR techniques indicated Paraloid B72 as a polymer used for consolidation (Fig. 3). The characteristic bands of Paraloid B72 broad strong band at $\approx 1452: 1480 \mathrm{~cm}^{-1}$ due to a methyl group of the ethyl methacrylate monomeric unit, $\mathrm{C}=\mathrm{O}$ stretching band of $\mathrm{CO}_{3}^{-2}$ at $\approx 1725 \mathrm{~cm}^{-1}$ and $\mathrm{O}-\mathrm{C}-\mathrm{O}$ bending band of Carbonate group at $\approx$ $865 \mathrm{~cm}^{-1}$. Small C-H stretching bands are in the range between 2988 and $2957 \mathrm{~cm}^{-1}$

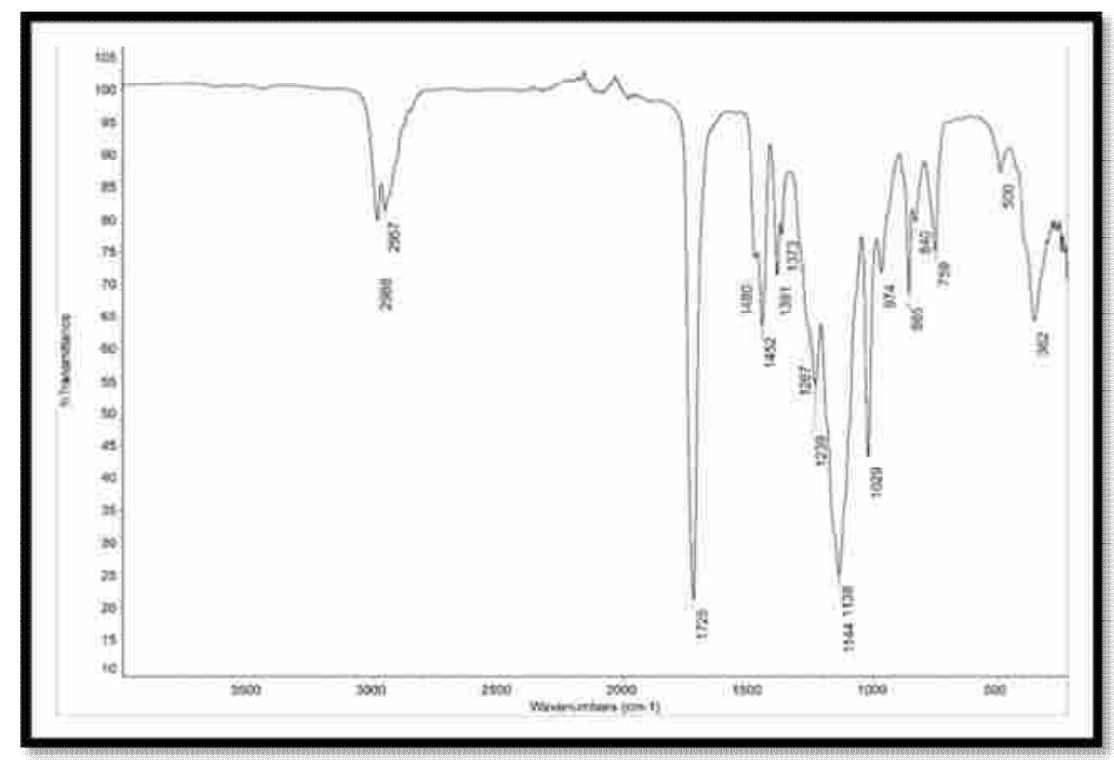

Fig.3. FTIR spectrum for the extracted acrylic material of the mural oil paintings of the mosque

\section{EDX-SEM}

The examination by SEM showed that the mural oil painting consists of two layers, the ground layer and the painted layer (Fig.4).

${ }^{28}$ Baglioni, et al, "Smart cleaning of cultural heritage: a new challenge for soft nanoscience", 2012

\footnotetext{
- 194 - Modification of EAPC-XYL by Pseudomonas lipases bacteria to remove acrylic ...
} 
Fig. 4: Scanning electron micrograph (SEM) indicates two layers (1) the ground layer,

(2) the painted layer full of polymers.

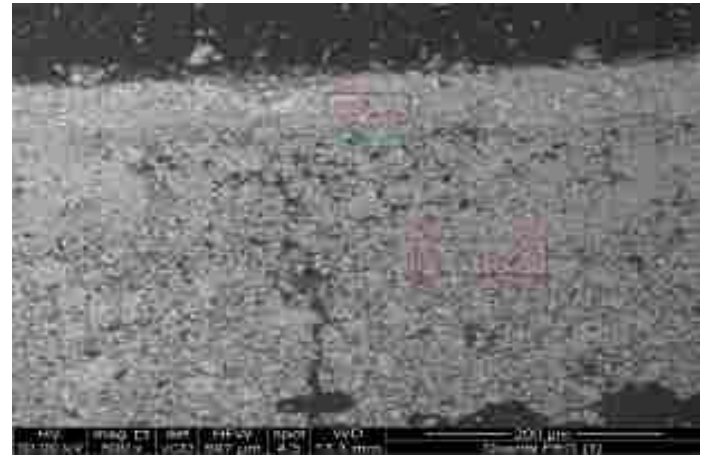

Even with the naked eye, the upper painted layer and the ground one appears to be consolidated several times with polymers and acrylic (Fig. 5). The EDX analysis shows high level of carbon beak.

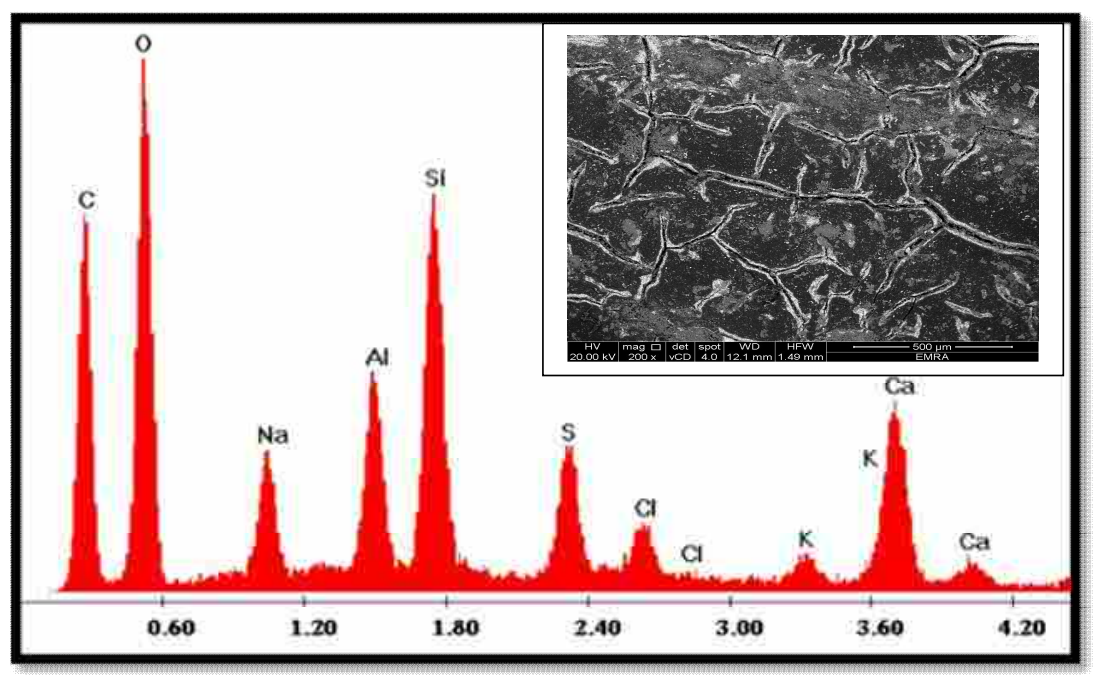

Fig. 5. Scanning electron micrograph showing the upper layer of the mural oil paintings.

\section{Viable cell counts}

Pseudomonas stutzeri growth rate at $35^{\circ} \mathrm{c}, \mathrm{pH}=7.5$ on broth medium showed the highest cell density (1.3 O.D. 550 and $>10.1 \log$ CFU ml ${ }^{-1}$ ) in the broth. ${ }^{29}$

\section{Application on the replica}

The application on the replica was performed under laboratory conditions on the mural oil paintings models. The models were consolidated by paraloid B72 5\% in Ethyl alcohol and aged (see 2.3). After ageing, all pigments were measured using a colourimeter before applying the nanoemulsion. The total colour change $(\Delta \mathrm{E})$ between the two perimeter colours is 3031

\footnotetext{
${ }^{29}$ ElHagrassy "Bio-restoration of mural paintings using viable cells of Pseudomonas stutzeri and characterization of these murals", 2019.

${ }^{30}$ Wyszecki and Stiles, "Color Science Concepts and Methods. Quantitative Data and Formulae”, 2000
} 


$$
\Delta \mathrm{E}^{*}=\left\{\left(\Delta \mathrm{L}^{*}\right) 2+\left(\Delta \mathrm{a}^{*}\right) 2+\left(\Delta \mathrm{b}^{*}\right) 2\right\} 1 / 2
$$

The cleaning process started by covering the replica with some Japanese paper $0.9 \mathrm{mg}$. Poultices made of cellulose pulp and immersed in the two different fluids were applied for several periods ( $1 \mathrm{~h}, 2 \mathrm{hrs}, 3 \mathrm{hrs})$ at room temperature (about $25^{\circ} \mathrm{C}$ ).

After that, the poultices were carefully removed and the pigments were measured again after application (Table 1,2). The pigments were examined using SEM before and after the application (Fig. 6-7). The FTIR analysis showed that the functional groups before and after treatment were completely different (Fig. 8).

Table 1. The $\triangle \mathbf{E}$ of the EAPC-XYL system on oil pigment before and after application

\begin{tabular}{|c|c|c|c|c|}
\hline Pigments & before & After $1 \mathrm{~h}$ & After $2 \mathrm{hrs}$ & After 3hrs \\
\hline Yellow & 40.22 & 40.25 & 40.36 & 40.52 \\
\hline Green & 46.82 & 46.89 & 46.92 & 47.16 \\
\hline Blue & 49.63 & 49.71 & 49.83 & 49.93 \\
\hline Red & 45.04 & 45.10 & 45.15 & 45.26 \\
\hline Green-Blue mix & 51.87 & 51.93 & 51.99 & 52.18 \\
\hline Black & 45.82 & 45.86 & 45.94 & 46.08 \\
\hline
\end{tabular}

Table 2. The $\triangle \mathbf{E}$ of the EAPC-XYL / Pseudomonas stutzeri cells on oil pigment before and after application

\begin{tabular}{|c|c|c|c|c|}
\hline Pigments & before & After 1h & After $2 \mathrm{hrs}$ & After 3hrs \\
\hline Yellow & 40.22 & 40.22 & 40.25 & 40.26 \\
\hline green & 46.82 & 46.85 & 46.85 & 46.88 \\
\hline Blue & 49.63 & 49.68 & 49.70 & 49.72 \\
\hline Red & 45.04 & 45.06 & 45.10 & 45.09 \\
\hline Green-Blue mix & 51.87 & 51.89 & 51.88 & 51.91 \\
\hline Black & 45.82 & 45.85 & 45.86 & 45.86 \\
\hline
\end{tabular}

\footnotetext{
${ }^{31}$ Atodiresei et al., Chromatic Characterization in Cielab System for Natural Dyed Materials, Prior Activation in Atmospheric Plasma Type DBD”, 2013
}

- 196 - Modification of EAPC-XYL by Pseudomonas lipases bacteria to remove acrylic ... 

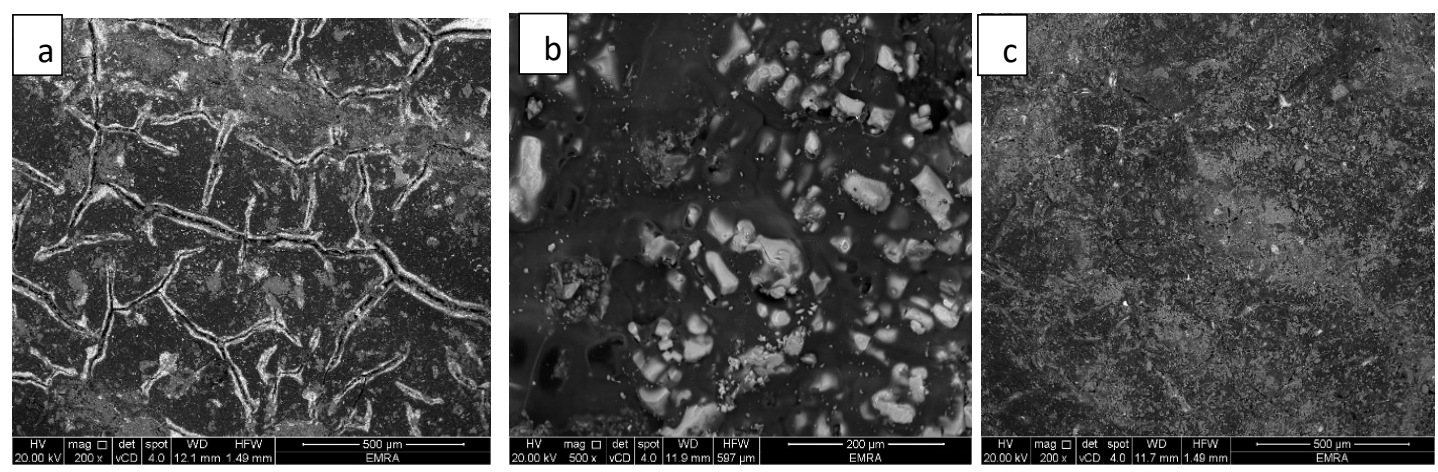

Fig 6. SEM micrograph presents (a) sample before application, (b) after $1 \mathrm{~h}$ of applied EAPC-XYL, (c) after $3 \mathrm{~h}$ of application
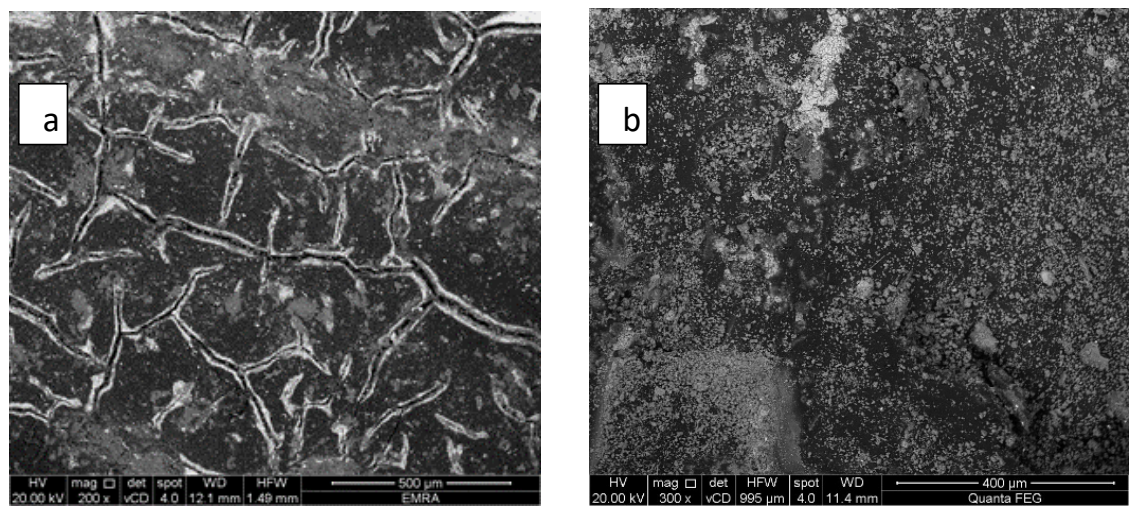

Fig 7. SEM micrograph presents (a) before application of EAPC-XYL / Pseudomonas stutzeri system, and (b) after $1 \mathrm{~h}$ of application. 


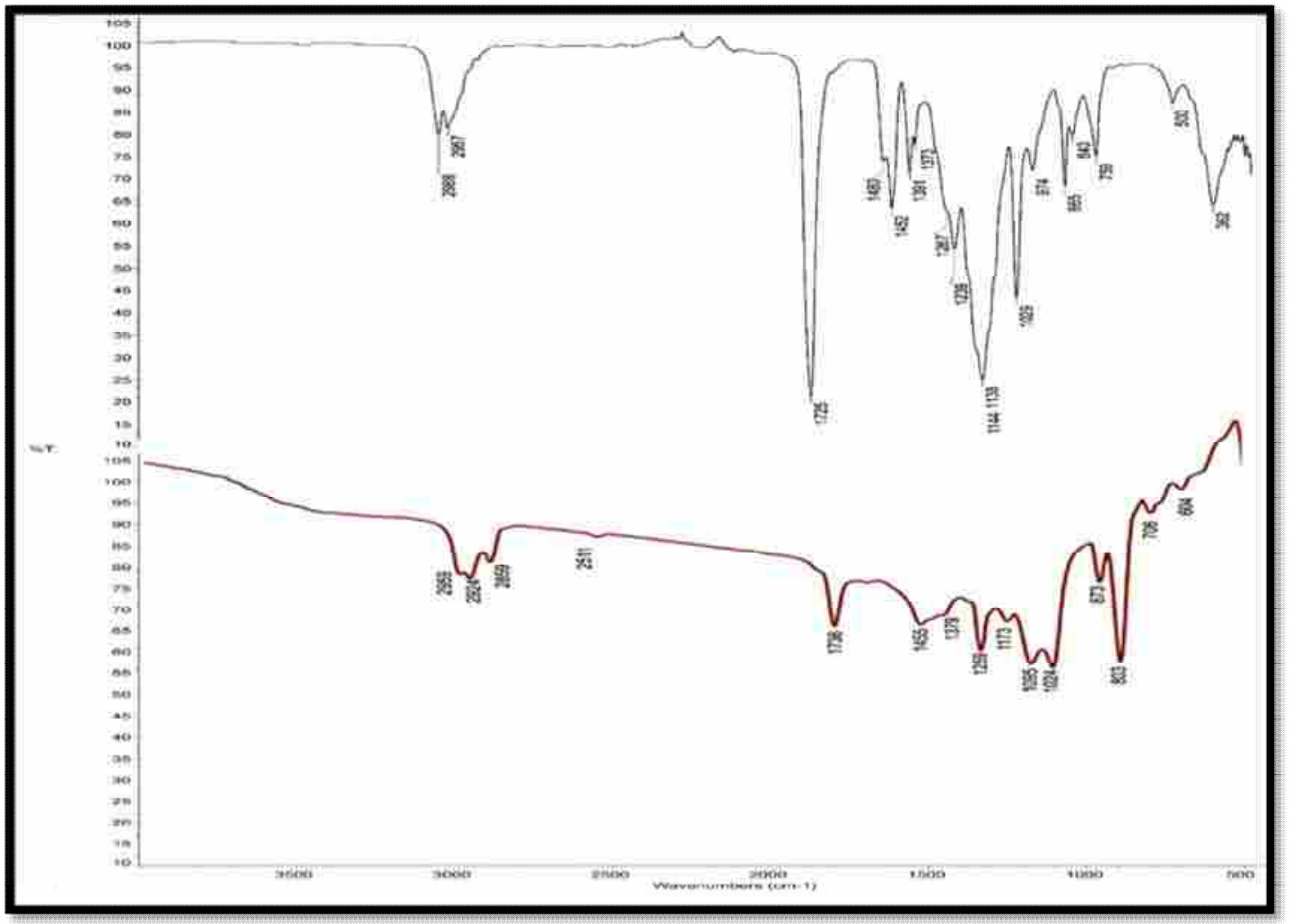

Fig 8. FTIR spectrum showing the upper curve represents the mural oil paintings before removing the acrylic, while the lower curve represents the oil binding media of the mural paintings.

\section{DISCUSSION}

The traditional methodologies for removing polymers and acrylics from mural oil paintings by using organic solvents or physical gels are considered unsuitable. The organic solvents are usually efficient in dissolving the polymer during the initial consolidation process. However, after polymerization, it becomes inefficient to use the same solvent to remove polymer or acrylic. $^{32}$

In addition, using high concentrations of organic solvents may cause a discolouration of the pigments of the mural paintings. Moreover, the toxicity and volatility of most solvents cannot be neglected, because conservators usually work in poorly ventilated environments. ${ }^{33} 34$

\footnotetext{
${ }^{32}$ Singh and Arbad, "Ancient Indian Painting Recipes and Mural Art Technique at Ajanta" 2014

33 Raudino, et al, "Polymer Films Removed from Solid Surfaces by Nanostructured Fluids: Microscopic Mechanism and Implications for the Conservation of Cultural Heritage" 2015

34 Giamblanco, et al, "Probing the cleaning of polymeric coatings by nanostructured fluids: A QCM-D study", 2017
}

\footnotetext{
- 198 - Modification of EAPC-XYL by Pseudomonas lipases bacteria to remove acrylic ...
} 
Removing polymers and acrylics by nano-fluids is safe and applicable compared to the use of organic solvents. The re-deposition of the removed polymer from the grains of the mural paintings is avoided due to the aqueous nature of the nano-fluid. 3536

In this study, EAPC-XYL and EAPC-XYL/ Pseudomonas stutzeri viable cell were applied on the replica for various duration of time. The results showed that using EAPC-XYL/ Pseudomonas stutzeri for only one hour has the same effect as using EAPC-XYL for three hours, due to the lipase enzymes that duplicate the effect of the nano-fluid. However, using EAPC-XYL/ Pseudomonas stutzeri has a low effect on the patina of the pigments. The spectrophotometer investigation showed that the $\triangle \mathrm{E}$ was lower when using EAPC-XYL/ Pseudomonas stutzeri than when using the EAPC-XYL.

The SEM of the replica treated with EAPC-XYL/ Pseudomonas stutzeri for one hour showed the grains of the pigments without the polymeric layers. The FTIR analysis confirmed that the cleaning process had succeeded, as the FTIR for the mural painting before the removal of acrylic showed the paraloid B72 that was used for consolidation. After the application of the EAPC-XYL/ Pseudomonas stutzeri for one hour and the removal of the cellulose poultices, the FTIR spectrum showed the functional groups of the oil binding media without the presence of paraloid B72.

EAPC-XYL/ Pseudomonas stutzeri system is more efficient and versatile than the EAPC$\mathrm{XYL}$ nanoemulsion system used in several previous studies. ${ }^{37} 38{ }^{39}$ Interactions between EAPC-XYL/Pseudomonas stutzeri and the polymer coating the layers were promoted in this study. It was hypothesised that EAPC-XYL/ Pseudomonas stutzeri system complies with a mechanism where many processes are taking place in the same time:

i) the aqueous phase (PC and EA) containing solvent interacts with the polymer, ${ }^{40} 41$

ii) Migration of solvents arises from the nano-droplets to the aqueous phase,

iii) Migration arises from nano-droplets to the polymer. ${ }^{42}$.

iiii) the lipase enzyme lets all the previous processes happen in a short time. As a final result, the polymer layer was swollen and was detached by the cellulose poultices which can be easily removed.

\section{CONCLUSIONS}

The removal of aged Paraloid B72 from the consolidated mural oil paintings without affecting the surface is possible by using EAPC-XYL/ Pseudomonas stutzeri. Observations

\footnotetext{
${ }^{35}$ Baglioni, et al, "Dewetting acrylic polymer films with water/propylene carbonate/surfactant mixtures Implications for cultural heritage conservation" 2017

${ }^{36}$ Baglioni, et al, "Polymer Film Dewetting by Water/Surfactant/Good-Solvent Mixtures: A Mechanistic Insight and Its Implications for the Conservation of Cultural Heritage" 2018

${ }^{37}$ Cappitelli, "Biocleaning of Cultural Heritage Surfaces" 2016

${ }^{38}$ Giorgi, et al, "Microemulsions for the cleaning of wall paintings", 2008

39 Giorgi, et al, "New methodologies for the conservation of cultural heritage: micellar solutions, microemulsions, and hydroxide nanoparticles",2010

${ }^{40}$ Baglioni, et al, "An amine-oxide surfactant-based microemulsion for the cleaning of works of art" $2015 \mathrm{a}$.

${ }^{41}$ Baglioni, et al, "Amphiphile-based nanofludis for the removal of styrene/acrylate coatings: Cleaning of stucco decoration in the Uaxactun archeological site (Guatemala)", 2015 b.

${ }^{42}$ Arroyo, "Development of innovative nanostructured systems for the cleaning of works of art", 2012
} 
by the SEM microscope indicated that the removal of acrylic was successful after only one hour. After the cleaning process, FTIR spectra revealed that there was no dispersed Paraloid within the mural painting layers. Moreover, the spectrophotometer investigation showed that the removal process of the acrylic was effective without altering the noble patina of the pigments. The proposed methodology is applicable, risk-free associated with organic solvents, as well as harmless for both the conservators and the mural oil paintings. 


\section{REFERENCES}

1. Arroyo (MC) "Development of innovative nanostructured systems for the cleaning of works of art" University of Florence (PhD dissertation), (2012).

2. Atodiresei (G.V), Sandu (I.G), Tulbure (E.A), Vasilache (V), Butnaru (R) "Chromatic Characterization in Cielab System for Natural Dyed Materials, Prior Activation in Atmospheric Plasma Type DBD" Revista de Chimie (Bucharest) 64, (2013), 165-169.

3. Baglioni (Michele), Montis (C), Brandi (F), Guaragnone (T), Meazzini (I), Baglioni (Piero), Berti (Debora) "Dewetting acrylic polymer films with water/propylene carbonate/surfactant mixtures - Implications for cultural heritage conservation" The Royal Society of Chemistry 19, (2017), 23723-23732.

4. Baglioni (Michele), Benavidesa (YareliJàidar), Bertia (Debora), Giorgia (Rodorico), Keiderling (Uwe), Baglion (Piero) "An amine-oxide surfactant-based microemulsion for the cleaning of works of art" Journal of Colloid and Interface Science 440, (2015), 204210.

5. Baglioni (Michele), Giorgi (Rodorico), Berti (Debora) and Baglioni (Piero) "Smart cleaning of cultural heritage: a new challenge for soft nanoscience" Nanoscale 4 (2012), 42-53.

6. Baglioni (Michele), Jáidar (Yareli), Alice (Benavidesa), Drapelab (Desprat), Giorgi (Rodorico) "Amphiphile-based nanofludis for the removal of styrene/acrylate coatings: Cleaning of stucco decoration in the Uaxactun archeological site (Guatemala)", Journal of Cultural Heritage 16 (2015), 862-868.

7. Baglioni (Michele), Montis (Costanza), Chelazzi (David), Giorgi (Rodorico), Berti (Debora) Baglioni (Piero) "Polymer Film Dewetting by Water/Surfactant/Good-Solvent Mixtures: A Mechanistic Insight and Its Implications for the Conservation of Cultural Heritage" Journal of German chemical society 57, Special Issue: Heritage Science Plus Analytical Chemistry, Spectroscopy, and Bioanalysis, ( 2018), 7355-7359

8. Baglioni, (Michele), Raudino (M), Berti, (D), Keiderling, (U), Bordes, (R), Holmberg (K) and Baglioni $(\mathrm{P})$ "Nanostructured fluids from degradable nonionic surfactants for the cleaning of works of art from polymer contaminants" Soft Matter 10 (2014), 6798- 6809.

9. Cappitelli (Francesca) "Biocleaning of Cultural Heritage Surfaces" The Open Conference Proceedings Journal 7, (2016), 65-69.

10. Carretti (Emiliano), Dei (Luigi), Baglioni (Piero), Miliani (C) "Oil-in-water microemulsions to solubilize acrylic copolymers: application in cultural heritage conservation" Trends in Colloid and Interface Science XV, (2001), 63-67.

11. Carretti (Emiliano), Giorgi (R), Berti (D), Baglioni (Piero) "Oil in water nanocontainers as low environmental impact cleaning tools for works of art: two case studies", Langmuir 23 (2007), 6396-6403.

12. Carretti (Emiliano), Salvadori (Barbara), Baglioni (Piero), Dei (Luigi) "Microemulsions and Micellar Solutions for Cleaning Wall Painting Surfaces", Studies in Conservation 50 (2005), 1-8.

13. ElHagrassy (Abeer) "Bio-restoration of mural paintings using viable cells of Pseudomonas stutzeri and characterization of these murals". International Journal of Archaeology, (2019).

14. Giamblanco (Nicoletta), Raudino (Martina), Montis (Costanza), Berti (Debora), Marletta (Giovanni), Baglioni (Piero) "Probing the cleaning of polymeric coatings by nanostructured fluids: A QCM-D study" Langmuir 33, (2017), 5675-5684

15. Giorgi (Rodorico), Baglioni (Michele), Berti (Debora), Baglioni (Piero) "New methodologies for the conservation of cultural heritage: micellar solutions, microemulsions, and hydroxide nanoparticles", Account of Chemical Research 43 (2010), 695-704. 
16. Giorgi (Rodorico), Chelazzi (David), Carretti (Emiliano), Falletta (Ester), Baglioni (Piero) "Microemulsions for the cleaning of wall paintings" ICOM Committee for Conservation, ICOM-CC, 15th Triennial Conference New Delhi, 22-26 September (2008), 527-533

17. Gupta (Ankur), Eral H. (Burak), Hatton T. (Alan) and Doyle S. (Patrick) "Nanoemulsions: formation, properties and applications", Soft Matter 12 (2016), 2826-2841.

18. Lustrato (G), Alfano (G), Andreotti (A), Colombini (M.P), Ranalli (G) "Fast biocleaning of mediaeval frescoes using viable bacterial cells" International Biodeterioration \& Biodegradation 69, (2012), 51-61.

19. Masaaki (S) "The consolidation and the conservation of ancient Japanese wall paintings", in International Symposium on the Conservation and Restoration of Cultural Property, National Research Institute of Cultural Properties, Nara (1996), 211-225.

20. Mora (Poulo) "Causes of Deterioration of Mural paintings", International center for the study of the preservation and restoration of cultural property, Rome, (1974).

21. Prada, (J.L). et al "Laboratory Tests Simulating the Weathering Processes of the Stone of Sant Miquel Church in Cardona (Barcelona, Spain), Protection and Conservation of Cultural Heritage of the Mediterranean Cities", A.A. Balkema Publishers, Lisse, (2002).

22. Raudino (Martina), Giamblanco (Nicoletta), Montis (Costanza), Berti (Debora), Marletta (Giovanni), Baglioni (Piero) "Probing the Cleaning of Polymeric Coatings by Nanostructured Fluids: A QCM-D Study" Langmuir 33, (2017), 5675-5684.

23. Raudino (Martina), Selvolini (Giulia), Montis (Costanza), Baglioni (Michele), Bonini (Massimo), Berti (Debora), Baglioni (Piero) "Polymer Films Removed from Solid Surfaces by Nanostructured Fluids: Microscopic Mechanism and Implications for the Conservation of Cultural Heritage" ACS Applied Materials and Interfaces 7, (2015), 6244-6253.

24. Rosado (T), Martins (M.R), Pires (M), Mirão (J), Candeias (A), Caldeira (A.T) "Enzymatic Monitorization of Mural Paintings Biodegradation and Biodeterioration" International Journal of Conservation Science, 4, (2013), 603-612.

25. Singh (M), Arbad (B.R) "Ancient Indian Painting Recipes and Mural Art Technique at Ajanta" International Journal of Conservation Science 5, (2014), 35-50.

26. Singha (Yuvraj), Mehera (Jaya), Ravala (Kavit), Ali (Farooq), Chaurasia (Mohini), Jainc (Nitin), Chourasiaa (Manish) "Nanoemulsion: Concepts, development and applications in drug delivery", Journal of Controlled Release 252 (2017), 28-49

27. Tintori (L) "Studies for the preservation of the frescoes by Giotto in the Scrovegni Chapel at Padua. The state of conservation of the frescoes and the principal technical conservation problems", Studies in Conservation 8, (1963), 37-41.

28. Wyszecki, (G), Stiles, (W. S), "Color Science Concepts and Methods. Quantitative Data and Formulae", Second Edition, John Wiley \& Sons, Inc. New York (2000). 